\title{
架空絶縁電線表面の沿面放電における インパルス電圧印加の影響
}

$\begin{array}{llllll}\text { 正 } & \text { 西 } & & \text { 敏 } & \text { 行 } & \text { (富山高専) } \\ \text { 正 } & \text { 員 } & \text { 岡 } & \text { 良 } & \text { (金沢工大) } \\ \text { 正員宮 本 紀 } & \text { 男 } & \text { (金沢工大) }\end{array}$

Influence of Applied Impulse Voltage on Creeping Discharges along Aerial Insulated Wire

\author{
Toshiyuki Nishi, Member(Toyama National College of Technology) \\ Ryoichi Hanaoka, Member(Kanazawa Institute of Technology) \\ Toshio Miyamoto, Member(Kanazawa Institute of Technology)
}

In high voltage aerial distribution systems, insulated wires are supported by insulators. If overvoltages caused by lightning occurr in the central line of an insulated wire, creeping discharges progress along the wire surface from the free end of the binding wire and bring about an accident such as punch-through breakdown, disconnection of wire. The clarification of breakdown phenomena in these insulation systems will contribute to the prevention of such accidents. These creeping discharges can take on complicated phenomena due to the change of the electric field intensity on the wire surface so that the potential of the central line of wire is changed by induced lightning.

In this paper, we report the influence of the voltage change of the central line on lengths and aspects of creeping discharge when a standard impulse voltage is applied to the central line or binding wire.

キーワート：架空絶縁電線，沿面放電，誘導雷，雷インパルス，雷害対策

\section{1.まえがき}

高圧架空配電系統において、絶縁電線の支持点では、電 線の心線、被覆、がいし、大地などにより複合的な絶縁系 が構成される。それ故、その支持点では、雷過電圧の侵入 により複雑な放電現象が発生し、電線溶断事故などの绿害 の原因となる(1)。このような断線事故に対しては、電線 表面に発生する沿面放電現象の解明が重要となるが、現状 では未解明な点が多く存在している。また、電線表面での 沿面放電は、平板上を放射状に進展する沿面放電と異なり、 円筒面上を直線状に進展するため、観測も容易であり物理 的にみても興味ある対象である。

著者らは、こ狄まで架空絶縁電線の心線に誘尊雷が侵入 した時、電線支持点で発生する絶縁破壊の機構を明らかに するため、がいし表面の絶縁破壊後に電線表面を進展する インパルス沿面放電の特性を検討してきた ${ }^{(2)}$ (5)。電線 $^{-1}$ 表面における沿面放電現象を複雑にしている要因として以 下のことが考えられる。まず第一に、架空絶縁電線は、雨、 雪などの自然現象にさらされること、第二に、誘導雷が電 線の心線に侵入するため沿面放電にとって背後電極となる
心線の電位が放電の進展とともに変化することなどである。 前者では、襲電時における降雨によって電線表面に水滴が 付着するため、そのような状況下の沿面放電現象仗電線表 面が乾燥状態のとさよりもさらに複雑になることが予想さ れる。乾燥、湿潤状態における沿面放電現象については、

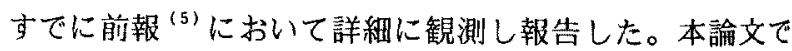
は、後者の心線電位変化の影響を明らかにするため以下の 実験を行った。すなわち、電線の心線にインパルス電圧を 印加した場合とその対比実験としてバインド線にインパル ス電仕を印加し、心線を接地してアース電位に固定した場 合の両者における沿面放電現象の相違について詳細な観湘

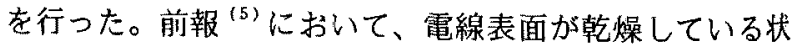
態で電線の心線にインパルス電圧を印加した場合、負極性 沿面放電の進展長は、印加電圧波高值（以下、 $\mathrm{V}_{\mathrm{m}}$ と記す） の上昇に伴って単調に增加する領域と逆に徐々に減少する 領域の二つに分けられることを明確にした。これは、 $\mathrm{V}$ により放電先端の様相が先端密着型と先端ジャンプ型 ${ }^{(5)}$ という二つの形態に変化し、それが進展長に影響を及ぼす ためである。

本論文においては、電線の心線またはバインド線にそれ 
それインパルス電圧を印加した場合の沿面放電の進展長と 進展様相の相違を比較険討した。その結果、負極性沿面放 電先端に現れる放電形態の変化 ${ }^{(5)}$ は、電線の心線にイン パルス電圧を印加した場合に現れる特有の現象であること が判明した。すなわち、電線の心線に誘導雷が侵入した場 合に発生する電線表面の沿面放電と背後電極がア一ス電位 に固定された場合の沿面放電とは異なる特性を示す。この ため、雷害刘策を検討する上で、このような特性の考虑が 重要であると考えられるのでここに報告する。

\section{2. 実験方法}

<2、1 1 実験回路実験回路を図 1（a）、 (b)に示す。（a）、（b）ともインパルス電圧発生器 （IG）により標準雷インパルス電圧 $( \pm 1.2 / 50 \mu \mathrm{s})$ を 発生させた。今回は、以下の二つの実験を行った。

実験 1 : 電線の心線に電圧印加（誘導雷サージ電圧が心 線に侵入した場合を模擬)

誘導雷を模擬するため電線の心線にインパルス電圧を印 加し、心線の終端は電圧波形の反射を防ぐためマッチング を行った。また、バインド線を放電電流観測用の抵抗 $(50$ $\Omega)$ を通して接地した。実際の架空絶縁電線は、バインド 線によってがいしに支持されているが、本実験では、がい

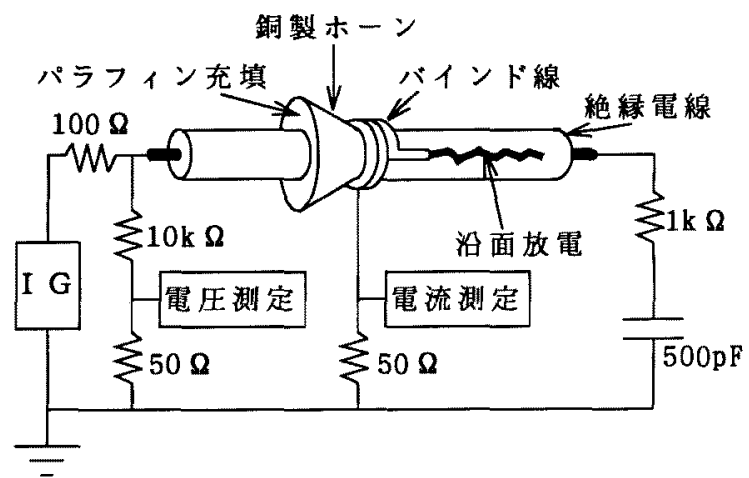

(a) 実験 1 ：心線に電圧印加（誘導雷サージ電圧を模擬）

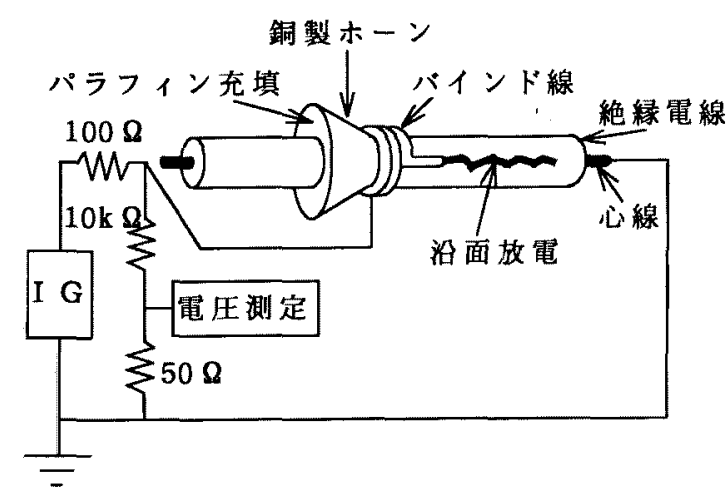

（b）実験 2 : バインド線に電圧四加

図 1 実験回路

Fig.1. Experimental circuit.
しがせん絡した状態を想定してがいしを実験回路から取り 除いた。

実験 2 : バインド線に電圧印加（実験 1 の対比実験）

電線の心線を接地し、バインド線に電圧を印加した。

実験 1、2 とも正極性、負極性沿面放電の進展長と進展 様相を詳細に観測し比較検討した。また、沿面放電は通常、 バインド線の両端から進展するが、観湘を容易にするため、 片側からのみ進展させるようにした。すなわち、（a）、

（b）のようにバインド線の片側に銅製ホーンを取り付け、 電線との間にパラフィンを充填してシールドした。バイン ド線は、その先端が垂直に切断された直径 $5.5 \mathrm{~mm}$ の合金 線（鉊97\%、アンチモン $3 \%$ ）であり、電線表面に軽く接 している。表 1 に絶縁電線の仕様を示す。電線の全長は5 $\mathrm{m}$ で、地上 $75 \mathrm{~cm}$ の高さに架設されている。また、実験 $1 、$ 2 の場合とも沿面放電進展後は、電線表面をアースし、ア ルコールで拭き残留電荷を除去した。また、実験室内は空 調を行い、気温約 $20^{\circ} \mathrm{C} 、$ 湿度約 $40 \%$ に保方実験条件を統一 して進展長のばらつきを極力抑えた。

なお、実験 1 の場合は、絶縁電線の心線に正極性のイン パルス電圧を印加したときは、バインド線先端から負極性 沿面放電が進展し、負極性のインパルス電圧を印加したと きは正極性沿面放電が進展することとなる。また、実験 2 の場合は、バインド線に印加したインパルス電圧の極性と 進展する沿面放電の極性は同一となる。

\section{3. 実験結果および考察}

\section{<3. 1 > 印加電圧波高值と沿面放電進展長の関} 係（I）正極性沿面放電図2は心線またはバイ ンド線にインパルス電圧を印加した場合における $V_{\mathrm{m}}$ と沿 面放電の進展長の関係を示す。各測定点は、10回の測定の 平均值を表し、進展長のばらつきは約士10\%であった。同 図より心線に電压を印加した場合の沿面放電（以下、放電 (実験 1 )と記す) とバインド線に電圧を印加した場合の 沿面放電（以下、放電（実験 2）と記す）の両者に進展長 の相違は見られず、いずれも $\mathrm{V}_{\mathrm{m}}$ の上昇に伴って単調に增 加する。

（II）負極性沿面放電图 3 は心線またはバインド線 に電圧を印加した場合における $V_{\mathrm{m}}$ と沿面放電進展長の関 係を示す。各測定点は、10回の測定の平均值である。進展 長のばらつきは、バインド線に電圧を印加した場合に約士 10\%であった。また、心線に電圧を印加した場合には $V_{m}$

\section{表 1 供試絶緣電線}

Table 1. Data of insulated wire.

\begin{tabular}{|c|c|c|c|c|c|c|c|}
\hline \multirow[b]{2}{*}{$\begin{array}{c}\text { 仕上が } \\
\text { り外径 } \\
\text { (西in) }\end{array}$} & \multirow[b]{2}{*}{$\begin{array}{l}\text { 全長 } \\
\text { (I) }\end{array}$} & \multicolumn{3}{|c|}{ 嗱 体 } & \multicolumn{3}{|c|}{ 絶 䋨 物 } \\
\hline & & $\begin{array}{l}\text { 公称 } \\
\text { 断面積 } \\
\left(\mathbb{M m}^{2}\right)\end{array}$ & 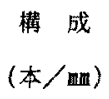 & $\begin{array}{l}\text { 外径 } \\
\text { (稫) }\end{array}$ & $\begin{array}{c}\text { 絶緑物 } \\
\text { の厚さ } \\
\text { (四) }\end{array}$ & 主材䓄 & $\begin{array}{l}\text { 比誘 } \\
\text { 電率 }\end{array}$ \\
\hline 10.0 & 5.0 & 22.0 & $7 / 2.0$ & 6.0 & 2.0 & 特归W & 2.3 \\
\hline
\end{tabular}




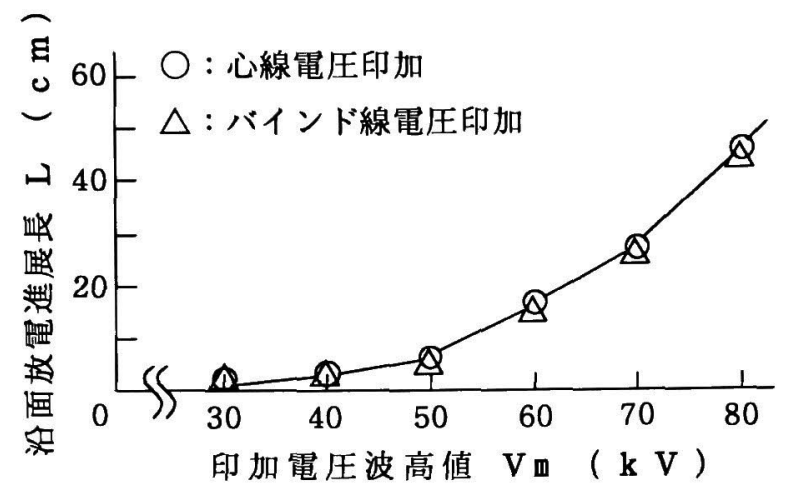

図 2 印加電圧波高値一沿面放電進展長特性 （正極性沿面放電）

Fig.2. Relation between peak value of applied impulse voltage and length of positive creeping discharge.

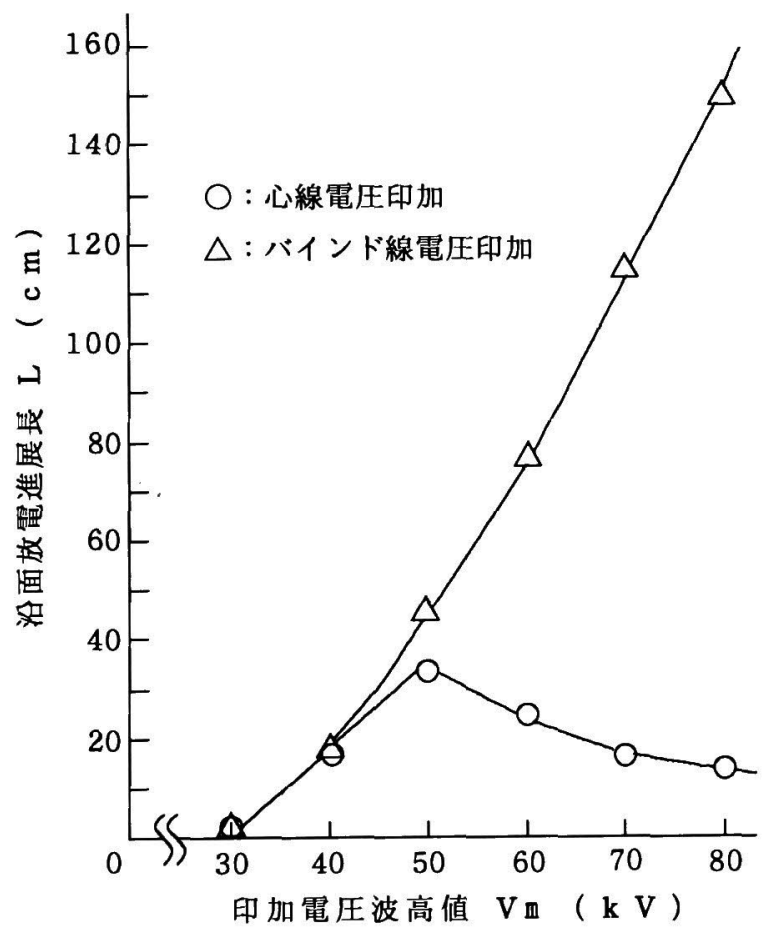

図 3 即加電圧波高値一沿面放電進展長特性 （負極性沿面放電）

Fig.3. Relation between peak value of applied impulse voltage and length of negative creeping discharge.

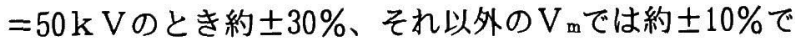
あった。放電（実験 1）の進展長は、 $\mathrm{V}_{\mathrm{m}} \leqq 50 \mathrm{kV}$ におい て $\mathrm{V}_{\mathrm{m}}$ の上昇と共に単調に増加し、 $\mathrm{V}_{\mathrm{m}}=50 \mathrm{kV}$ で進展長の 平均値が最大となる。その後、 $\mathrm{V}_{\mathrm{m}}>50 \mathrm{kV}$ ではしだいに 減少する ${ }^{(5)}$ 。一方、放電 (実験 2 ) の進展長は、 $V_{m}$ の上 昇に伴って単調に増加し、特に、 $V_{\mathrm{m}} \geqq 40 \mathrm{kV}$ での進展長 は、放電（実験 1 ）とは非常に異なった特性を示す。例え

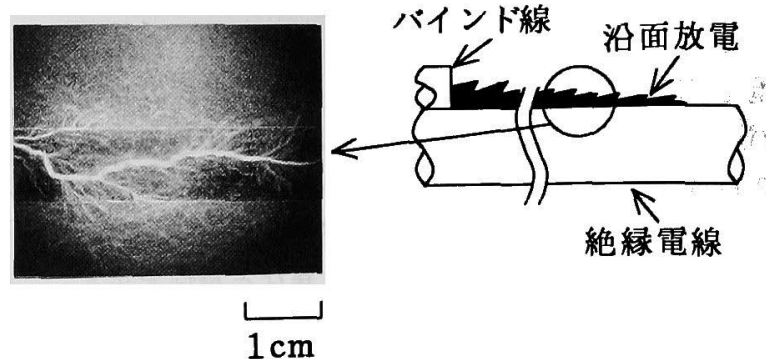

進展途中の様相

(パインド線先端より $20 \mathrm{~cm}$ の位置)

$\mathrm{V} \mathrm{m}=70 \mathrm{k} \mathrm{V}, \mathrm{L}=29 \mathrm{c} \mathrm{m}$

図 4 正極性沿面放電の進展様相

（バインド線に電圧印加）

Fig.4. Typical aspect of positive creeping discharge. Impulse voltage was applied to binding wire.

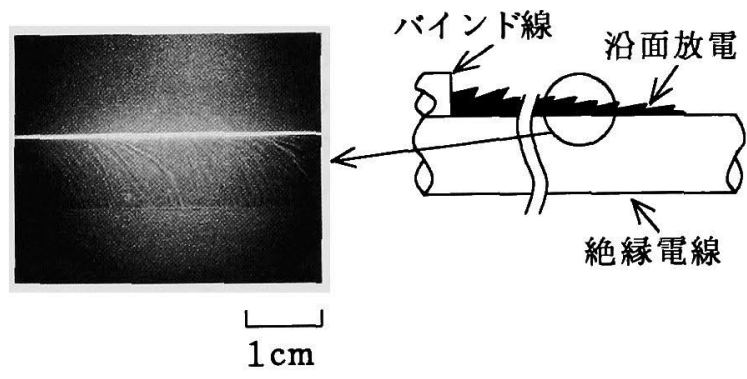

進展途中の様相

(パインド線先端より $20 \mathrm{c} \mathrm{m}$ の位圆)

$\mathrm{Vm}=-70 \mathrm{k} \mathrm{V}, \mathrm{L}=116 \mathrm{~cm}$

図 5 負極性沿面放電の進展椂相

(バインド線に電圧印加)

Fig.5. Typical aspect of negative creeping discharge. Impulse voltage was applied to binding wire.

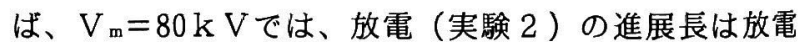
（実験 1 ）のそれの約11倍となっている。また、 $V_{\mathrm{m}} \leqq 40$ $\mathrm{kV}$ では、放電（実験 2 ）と放電（実験 1 ）の進展長はほ とんど等しい。さらに、 $V_{\mathrm{m}}=50 \mathrm{kV}$ Vおける進展長は、 放電（実験 2 ）の方が放電（実験 1 ）よりわずかに長くな っている。これらの理由については、く3．2>で詳述す る。

また、図 2、図 3 を比較すると、放電（実験 1 ）の場合、

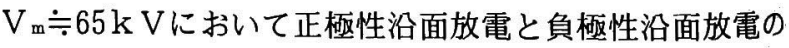
進展長の逆転が見られる。一方、放電（実験 2 ）では、負 極性沿面放電の進展長の方が正極性沿面放電よりも常に長 くなっている。

<3. $2>$ 治面放電の進展様相 図 4、図 5 はバ インド線に電圧を印加した場合（放電（実験 2））におけ る正極性及び負極性沿面放電の典型的な進展様相を示す。 これは、静止カメラにイメージインテンシファイヤを装着 

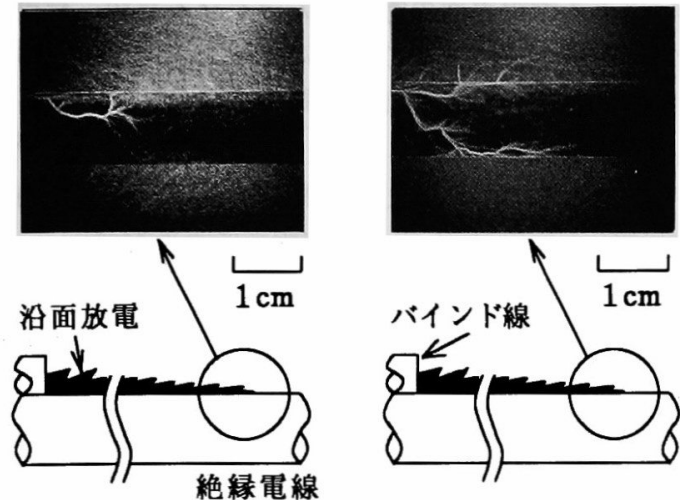

（a ）バインド線に電圧印加

(b ）心線に電圧印加

$\mathrm{V}$ m $=70 \mathrm{k} \mathrm{V}, \mathrm{L}=30 \mathrm{c} \mathrm{m}$

$\mathrm{Vm}=-70 \mathrm{k} \mathrm{V}, \mathrm{L}=28 \mathrm{c} \mathrm{m}$

図 6 正極性沿面放電先端の様相

Fig.6. Typical aspects near the tip of positive creeping discharge. Impulse voltage was applied to binding wire or central line of wire.
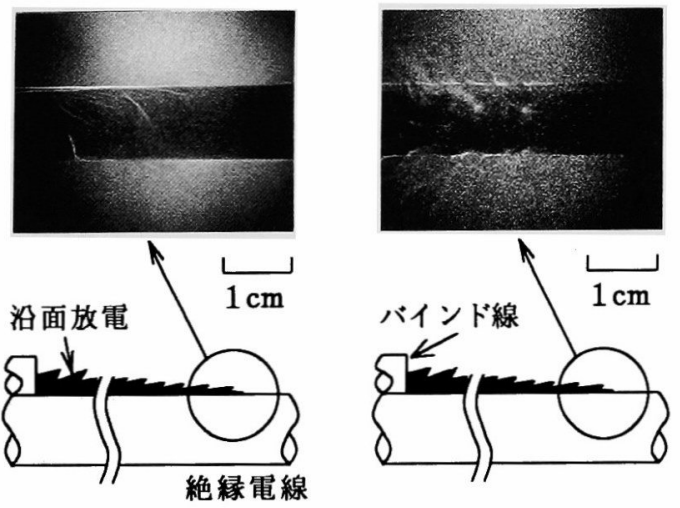

（a ）バインド線に電圧印加

\section{（b ）心線に電圧印加}

$\mathrm{V}$ m $=-70 \mathrm{k} \mathrm{V}, \mathrm{L}=115 \mathrm{c} \mathrm{m}$

$\mathrm{V} \mathbf{m}=70 \mathrm{k} \mathrm{V}, \mathrm{L}=18 \mathrm{c} \mathrm{m}$

図 7 負極性沿面放電先端の様相

Fig.7. Typical aspects near the tip of negative creeping discharge. Impulse voltage was applied to binding wire or central line of wire.

することにより撮影されたものである。両図は共にバイン ド線先端から 20 c m の位置における進展様相である。図 4 は正極性沿面放電（実験 2 ）の進展様相を示し、 $V_{m}=70$ $\mathrm{kV}$ 、進展長は $29 \mathrm{c} \mathrm{m}$ であった。沿面放電は電線表面から ジャンプしながら進展しており、正極性沿面放電（実験 1) で得られる進展形態 ${ }^{(5)}$ と同様であった。図 5 は、負極性 沿面放電（実験 2 ）の進展様相を示し、 $V_{m}=-70 \mathrm{k} \mathrm{V}$ 、 進展長は $116 \mathrm{c} \mathrm{m}$ であった。沿面放電は電線表面に密着し て進展し、電線側面に細い筋状の放電が認められる。これ は、負極性沿面放電 (実験 1 ) の放電先端以外の部分で見 られた様相 ${ }^{(5)}$ と同様である。すなわち、進展途中におけ る負極性沿面放電の進展様相は、バインド線、心線のいず れに電圧を印加しても変化しないことがわかる。
図 6（a）、（b ）は正極性沿面放電（実験 2）と（実 験 1 ) における放電先端の典型的な様相を示したものであ る。（a）は、バインド線に電圧を印加した場合で、 $V_{m}$ $=70 \mathrm{k} \mathrm{V}$ 、進展長は $30 \mathrm{c} \mathrm{mであった。また、（b} \mathrm{）は、心}$ 線に電圧を印加した場合で、 $\mathrm{V}_{\mathrm{m}}=-70 \mathrm{k} \mathrm{V}$ 、進展長は28 c mであった。両図より正極性沿面放電先端では、バイン ド線、心線のいずれに電圧を印加しても放電先端は電線表 面からジャンプしていることがわかり、進展様相に相違は 見られない。すなわち、正極性沿面放電では、放電（実験 2 )、放電（実験 1 ）のいずれもバインド線先端から放電 先端まで電線表面をジャンプしながら進展し、両者には進 展様相の相違が認められない。これが、図 2 に示された正 極性沿面放電の進展特性において、放電（実験 2 ）と放電 (実験 1 ) に相違が現れない理由になると考えられる。

図 7 ( a )、（b ）は、負極性沿面放電（実験 2 ）と (実験 1 ) の放電先端の典型的な様相を示したものである。 （a）はバインド線に電圧を印加した場合で、 $V_{m}=-70$

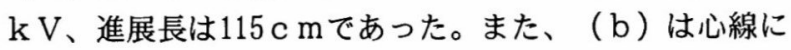
電圧を印加した場合で、 $\mathrm{V}_{\mathrm{m}}=70 \mathrm{kV}$ 、進展長は $18 \mathrm{c} \mathrm{m}$ で あった。（a）より負極性沿面放電（実験 2 ）の放電先端 は電線表面に密着していることがわかる。一方、（b）よ り負極性沿面放電（実験 1 ）の放電先端は、 $V_{\mathrm{m}} \geqq 70 \mathrm{k} \mathrm{V}$ において常にジャンプしている ${ }^{(5)}$ 。バインド線に電圧を 印加した場合における負極性沿面放電（実験 2 ）は、 $V_{m}$ の值に関わらず常に電線側面に細い筋状の放電を伴いなが ら電線表面に密着して進展し、その密着状態は、放電先端 まで連続しており決してジャンプすることはない。前報 ${ }^{(5)}$ で報告したように負極性沿面放電が進展するためには、放 電先端が電線表面に密着していることが重要である。負極 性沿面放電 (実験 2 ) は、 $\mathrm{V}_{\mathrm{m}}$ の值に関わらず、放電先端 が常に電線表面に密着している。このため、進展長は $V_{m}$ の上昇に伴って単調に増加し、負極性沿面放電 (実験 1 ) の場合に見られるような進展長の急変（図３）は現れない。 負極性沿面放電（実験 1 ）の放電先端は、 $\mathrm{V}_{\mathrm{m}} \leqq 40 \mathrm{k} \mathrm{V}$ の 電圧範囲で常に電線表面に密着している ${ }^{(5)}$ ため、図 3 の ように、放電（実験 2 ）と放電（実験 1 ）の進展長は等し

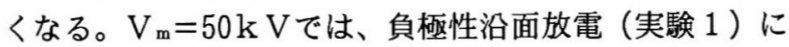
おいて放電先端が電線表面からジャンプして進展長が短く なるような先端ジャンプ型がほほ $50 \%$ 含まれている ${ }^{(5)}$ 。 そのため、進展長の平均は、放電先端が常に電線表面に密 着する負極性沿面放電（実験 2 ）より（実験 1 ) の方がわ ずかに短くなる。また、 $\mathrm{V}_{\mathrm{m}} \geqq 60 \mathrm{kV}$ では、負極性沿面放 電（実験 1 ）において、先端ジャンプ型の発生割合が増え る $^{(5)}$ 。従って、負極性沿面放電（実験 1 ）の進展長は、 進展長の長い先端密着型のみが存在する負極性沿面放電 (実験 2 ) よりも短くなる。

図8（a）〜（c）はバインド線または心線に電圧を印 加した場合における正極性及び負極性沿面放電の進展様相 の概略を模式的に示したものである。（a）は正極性沿面 放電（実験 2 ）及び（実験 1 ）の場合である。放電はバイ 


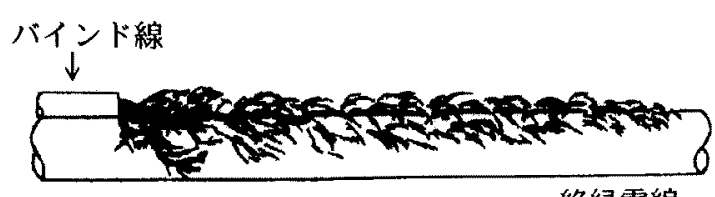

（a）正極性沿面放電

絶縁電線

(バインド線または心線に電圧印加）

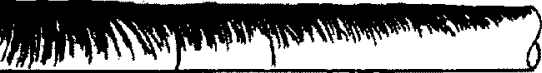

（b）負極性沿面放電

(バインド線に電圧印加)

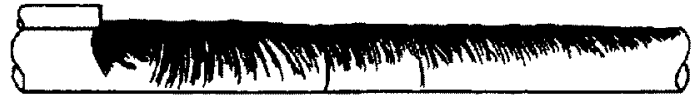

$(\mathrm{c}-1)$ 先端密着型

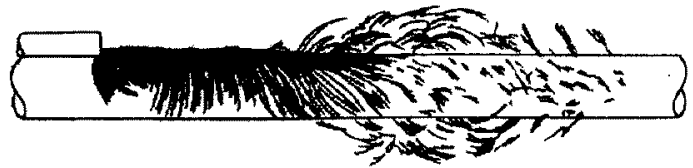

$(\mathrm{c}-2)$ 先端ジャンプ型

（c）負極性洽面放電

（心線に電圧印加）

図 8 沿面放電進展様相の模式図

（バインド線または心線に電圧印加）

Fig.8. Schematic diagrams of positive and negative creeping discharges. Impulse voltage was applied to binding wire or central line of wire.

ンド線先端から放電先端まで常にジャンプしながら進展し、 電圧をバインド線、心線のいずれに印加してもその進展長、 進展様相は変化しない。（b）、（c）はそれそれれ負極性 沿面放電（実験 2）及び（実験 1）の椂相の概略である。 （b）の放電（実験 2 ）の様相は、 $\mathrm{V}_{\mathrm{m}}$ の值に関わらずバ インド線先端から放電先端まで常に電線表面に密着してお り、電線側面に細い筋状の放電を伴っている。一方、放電 (実験 1) は、 $(c-1) 、(c-2)$ に示すように、放 電先端の形態は $V_{\mathrm{m}}$ の值によって先端密着型と先端ジャン プ型の 2 種類が存在する ${ }^{(5)}$ 。

有限半径を有する電線では、沿面放電（実験 2 ）と（実 験 1 ）のいずれにおいても電線表面の電界は、放電進展に 伴って生ずる電線表面の帯電電荷により変化する。しかし、 放電（実験 1) では、それ以外に、心線に印加されたイン パルス電圧による電界が電線表面に生じ、そのため電線表 面上を進展する沿面放電はその電界の影響を受けることに なる。 $V_{\mathrm{m}}$ が低いときは、心線電位による電線表面の電界 が小さいため、負極性沿面放電（実験 1 ）はその影響を受 けず放電先端は電線表面に密着し、進展長、進展様相とも 放電（実験 2 ）と同様になる。一方、 $\mathrm{V}_{\mathrm{m}}$ が高くなると、
心線電位による電線表面の電界が大きくなるため、負極性 沿面放電（実験 1) は、その影響によって放電先端が電線 表面からジャンプし、進展長は放電（実験 2 ）より短くな る。負極性沿面放電先端が、ジャンプし始めるときの $\mathrm{V}_{\mathrm{m}}$ を前報 ${ }^{(5)}$ ではジャンプ現象誘発電圧 $V_{j}$ と定義し、 $V_{j} に$ よる電線表面の電界 $\mathrm{E}_{\mathrm{j}}$ を表 1 の電線で求めた結果、 $\mathrm{E}_{\mathrm{j}} \doteqdot$ $19 \mathrm{kV} / \mathrm{cm}$ m゙った。

放電（実験 2 ）では、心線を接地しバインド線に電圧を 印加しているため、電線表面の電界は、沿面放電が進展し た部分のみ変化し、沿面放電は外部加らの電界によって影 響を受けることはない。このように心線に電圧を印加した 場合には、心線電位の変化に伴う電線表面電界の変化が沿 面放電に影響を及ほし、それが誘導雷の侵入による電線表 面の浻面放電現象を一層複雑にする原因となっている。

<3. $3>$ 負極性治面放電（心線に電圧印加、先端 シャンブ型）先端における放電様相の推移図9（a)

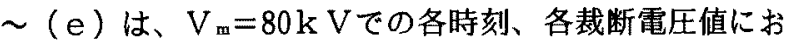
ける負極性沿面放電（実験 1 ）の典型的な放電先端の様相 を示す。これは、イメージインテンシファイヤ付き静止カ メラにより先端ジャンプ型を形成する沿面放電を電圧裁断 法によって各時刻こととに観測したものである。（a）〜 （e）は同一の放電ではないが、放電先端の様相が電圧田 加の後、時間の経過と共にどの様に変化していくかを知る

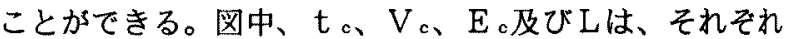
電圧裁断時刻、裁断電圧、Voにおける電線表面の電界 ${ }^{(5)}$ 、 沿面放電進展長を示す。

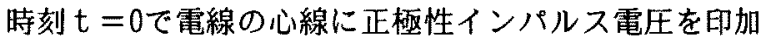
した場合に、（a）の時刻では、まだ゙インド線先端から 放電の進展は開始されていない。（b）において、放電は 既に進展を開始しているが、この時刻ではまだ、放電先端 は電線表面に密着したままである。（c）においては、 (c - 1) のように放電先端が電線表面に密着している場 合もあれば、（c-2）のように既にジャンプしている場 合もあるが、いずれにせよ放電先端にジャンプ現象が現れ る電圧はこのときの $\mathrm{V}$ 。付近である。V によよる電線表面の 電界 $\mathrm{E} \mathrm{c}$ を求めると、 $\mathrm{E}_{\mathrm{c}}=19.4 \mathrm{kV} / \mathrm{c} \mathrm{m}$ となり、 $\mathrm{E}_{\mathrm{j}}$ に ほほ一致している。この電圧值では、放電先端のジャンプ の度合はまだ弱く、形状は円弧状となり、密着型からジャ ンプ型への移行状態にあると言える。（d）においても

$(\mathrm{d}-1) 、(\mathrm{~d}-2)$ のように放電先端が電線表面に密 着している場合と既にジャンプしている場合の両者が存在 する。しかし、ジャンプする場合には、 $(\mathrm{d}-2)$ のよう に放電先端で激しくジャンブし、このときの電圧值におけ る放電は円弧状ではなく離散的な形態となり複雑な様相を 呈している。（e）の時刻ではもはや、放電先端は電線表 面に密着せず、激しくジャンプすることとなる。

\section{4. 結論}

標準雷インパルス電圧を模擬誘導雷として絶縁電線の心 線に印加した場合及びその対比実験としてバインド線に印 


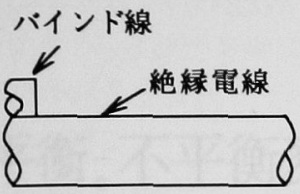

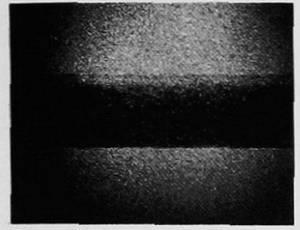

(a) $\mathrm{t}_{\mathrm{c}}=0.3 \mu \mathrm{s}, \mathrm{V}_{\mathrm{c}}=14.7 \mathrm{kV}$,

$$
\mathrm{L}=0 \mathrm{~cm}
$$

$t_{c}=0.45 \mu \mathrm{s}, \mathrm{V}_{\mathrm{c}}=40.1 \mathrm{kV}$ 沿面放電

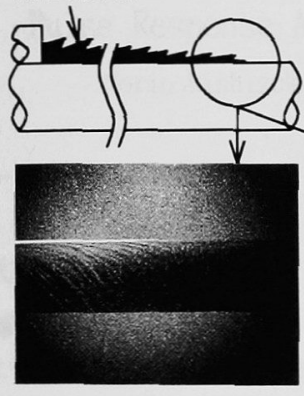

$(c-1) \mathrm{L}=11 \mathrm{~cm}$ (c) $\mathrm{t} c=0.85 \mu \mathrm{s}, \mathrm{V}_{\mathrm{c}}=50.7 \mathrm{kV}, \mathrm{E}_{\mathrm{c}}=19.4 \mathrm{kV} / \mathrm{cm}$

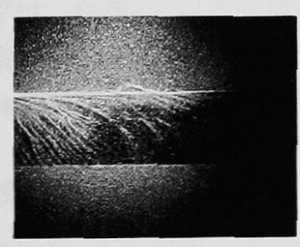

$(\mathrm{d}-1) \mathrm{L}=14 \mathrm{~cm}$

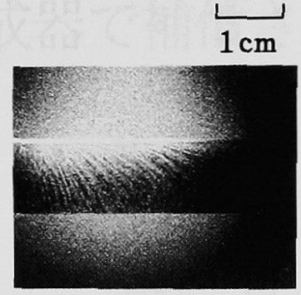

$\mathrm{E}_{\mathrm{c}}=15.3 \mathrm{kV} / \mathrm{cm}, \mathrm{L}=3.8 \mathrm{~cm}$
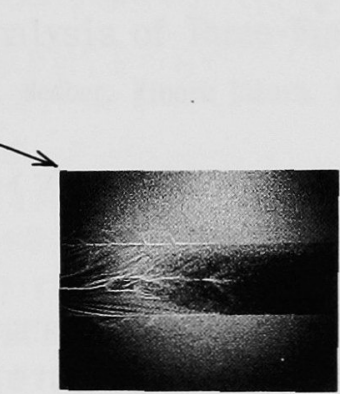

$(\mathrm{c}-2) \mathrm{L}=10 \mathrm{~cm}$

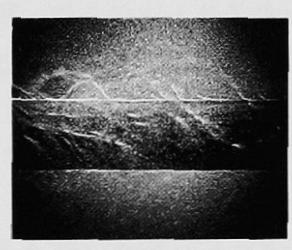

( d -2$) \mathrm{L}=12 \mathrm{~cm}$

(d) $\mathrm{t} c=0.9 \mu \mathrm{s}, \mathrm{V}_{\mathrm{c}}=62.7 \mathrm{kV}, \mathrm{E}_{\mathrm{c}}=24.0 \mathrm{kV} / \mathrm{cm}$

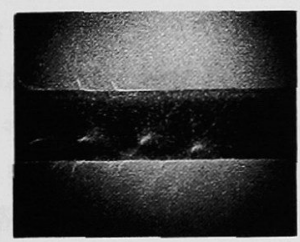

(e) $\mathrm{t}_{\mathrm{c}}=1.6 \mu \mathrm{s}, \mathrm{V}_{\mathrm{c}}=73.4 \mathrm{kV}$,

$\mathrm{E}_{\mathrm{c}}=28.1 \mathrm{kV} / \mathrm{cm}, \mathrm{L}=18 \mathrm{~cm}$

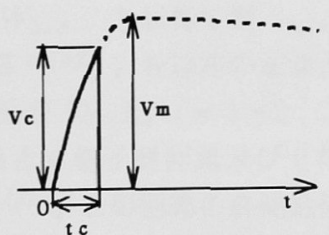

裁断電圧波形

図 9 負極性沿面放電先端における放電様相の推移 (心線に電圧印加、先端ジャンプ型、 $V_{m}=80 \mathrm{k} \mathrm{V}$ )

Fig.9. Typical change of aspects near the tip of negative creeping discharge. Impulse voltage at $\mathrm{Vm}=80 \mathrm{kV}$ was applied to central line of wire .

加した場合についてバインド線先端から進展する正極性及 び負極性沿面放電の進展長と進展様相を詳細に観測した結 果、以下のような新しい知見が得られた。

(1) 正極性沿面放電

(a) 進展長について

心線、バインド線のいずれに電圧を印加してもその
進展長に相違は見られず、印加電圧波高值の上昇に伴 って単調に増加する。

(b) 進展様相について

心線、バインド線のいずれに電圧を印加してもその 進展様相は変化せず、電線表面をジャンプしながら進 展する。

（2）負極性沿面放電

（a）進展長について

(1)心線に電圧を印加した場合

印加電圧波高值の上昇とともに進展長の増加す

る領域と減少する領域が存在する。

(2)バインド線に電圧を印加した場合

進展長は、印加電圧波高値の上昇に伴って単調 に増加する。

(b) 進展様相について

(1)心線に電圧を印加した場合

印加電圧波高值によって、放電先端が電線表面 に密着する場合とジャンプする場合の 2 通りが存 在する。

(2)バインド線に電圧を印加した場合

印加電圧波高值が変化しても放電先端は常に電

線表面に密着し、ジャンプすることはない。

（３）負極性沿面放電の先端が電線表面からジャンプし、 進展長が変化する現象は、心線に誘導雷サージ電圧が侵入 する場合のみであり、このことが配電線の支持点近傍にお ける放電現象を複雑にする一因となっている。

(平成 8 年 5 月 15 日受付)

$\frac{\text { 文 }}{\text { （1）電気協同研究会：「配電線雷害対策」、電気協同研 }}$ 究、第 40 巻、第6号 (昭60-2)

（2）西 敏行・櫻野仁志・石橋鐐造・高嶋 武：「架空 絶縁電線のがいし支持点近傍におけるインパルス沿 面放電特性」, 電学論 $B, 110,209$ (平2-3)

（3）西 敏行・櫻野仁志・石橋鐐造・高嶋 武：「絶緑 電線表面における連続インパルス沿面放電の特性」， 電学論 $B, 111,1269$ (平3-12)

(4) T.Nishi, R.Hanaoka, R.Ishibashi \& T.Korin:"Impulse Creeping Discharge Phenomena at Insulator Supporting Point of Aerial Insulated Wire",CEIDP,Annual Report, P.586(1993)

（5）西 敏行・花岡良一・石橋鐐造：「架空絶縁電線表 面における乾燥、湿潤状態での沿面放電現象」，電 学論 $\mathrm{B}, 116,482$ (平8-4) 
西解行 (正員) 1959年 3 月 8 日生まれ。83年 3 月 金沢大学大学院工学研究科修士課程修了。 同年 4 月ユーザック電子工業（株）〔現、 （株） P F U了入社。85年 4 月富山工業高 等専門学校電気工学科助手、93年 7 月同講 師、現在に至る。主として、沿面放電現象 に関する研究に従事。

花岡 良一（正員）1950年 1 月12日生まれ。80年 3 月

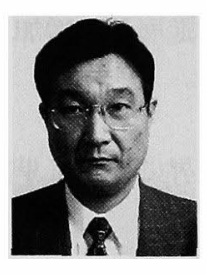
金沢大学大学院工学研究科修士課程修了。 88年 4 月金沢工業大学電気工学科講師、 89 年同助教授、96年同教授、現在に至る。主 として、液体誘電体中の電気伝導と絶縁破 壊及び電界計算法に関する研究に従事。93 年 9 月 94年 8 月米国 MIT 客員研究員。 工学博士。応用物理学会会員、IEEE 会員。

宮本 粑男 （正員）1937年 2 月11日生まれ。59年 3 月

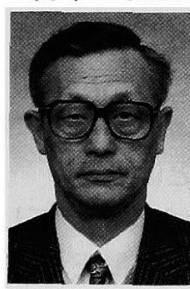
金沢大学工学部電気工学科卒業。同年 4 月 三菱電機（株）入社。中央研究所にて、永 久ヒューズ、S F 6 ガス絶縁変電機器など の開発に従事。80年伊丹製作所開発部長、 85年同所光ディスク開発プロジェクト部長、 87年産業システム研究所光ディスク開発セ ンター長、90年金沢工業大学教授。現在に至る。主として、 植物が示す神秘的な電磁気現象の研究に従事。工学博士。 電気学会准歩賞、科学技術庁長官賞受賞。 